\title{
Regulation and the Cost of Capital
}

Tim Jenkinson

Saïd Business School, Oxford University and CEPR

\section{Forthcoming in the International Handbook on Economic Regulation, edited by Michael Crew and David Parker, Edward Elgar, 2006}

\section{Introduction}

The cost of capital is one of the most important factors that regulators, and companies, have to estimate. The appropriate cost of capital for regulated industries has been debated extensively in many countries, in particular the US with its general (although not exclusive) reliance on rate of return regulation. However, in recent years, the cost of capital debate has been particularly active in the UK, where regulation tends to be on the basis of price-caps (or, in some cases, revenue caps). This paper reviews the way that regulators in the UK (including the Competition Commission ${ }^{1}$ ) have estimated the cost of capital, and discusses some important issues that remain unresolved.

With the regulatory asset values (RAVs) of the UK water, energy and rail networks alone approaching $£ 100$ billion $^{2}$, even small changes in the allowed return on such asset bases can have significant implications for customer bills. In addition, these are

\footnotetext{
${ }^{1}$ The predecessor to the Competition Commission (CC) was the Monopolies and Mergers Commission (MMC). However, in this paper occasionally, as a shorthand, we refer to decisions by either body as being those of the CC.

2 The regulatory asset values have recently been estimated at $£ 35$ billion for the England and Wales water sector (OFWAT, 2004), at $£ 12.5$ billion for electricity distribution (OFGEM, 2004a), at $£ 10.7$ billion for gas distribution (from NGT estimates associated with the sale of some of the local networks), at $£ 20.2$ billion for the rail infrastructure (ORR, 2003, p.269), at around $£ 5$ billion for electricity transmission (OFGEM, 2000) and at $£ 13$ billion for gas transmission. All these figures relate to the estimated RAV at April 2005. The price bases differ somewhat (between 2000 and 2003 prices) although converting into current prices would have a minor upward effect upon the estimates.
} 
by no means the only assets where the rate of return is regulated: certain airports, parts of mobile phone networks, the air traffic control system, the Royal Mail, and even Yellow Pages are also subject to explicit regulation. Furthermore, in many competition cases, the relationship of the observed rate of return to the estimated cost of capital is a key concern.

The main issues discussed in this paper are closely related. First, we discuss the difficulties observed in practice in estimating risk, and the appropriate equity cost of capital. Second, for regulated utility companies, the trend towards high levels of debt in their capital structures has become a source of concern for regulators. We discuss the question of whether, in addition to setting the cost of capital, the capital structure of companies should be regulated. Third, as debt has increased, the issue of "financeability" - whether the projected revenues, profits and cash flows are such as to enable the company to maintain a strong credit rating - has increasingly become a focus of attention. We consider whether adjustments to the required returns should be made to address concerns regarding financeability in the latter part of the chapter.

To provide a background to these current issues, the paper begins by defining terms and considering the recent history of regulatory judgements on the cost of capital, and draws comparisons with some of the key market evidence.

\section{How have regulators estimates of the cost of capital evolved?}

The cost of capital represents the minimum expected return required by investors in order to commit funds to a particular company or project. Much of the complexity associated with estimating the cost of capital derives from the difficulty of observing the expectations of investors. This is not too much of a problem in the case of debt investors, as interest rates provide forward-looking measures of market expectations for various credit qualities. The main problems are associated with estimating expected equity returns. In the absence of an observable market measure, it is necessary to use an appropriate asset pricing model to derive an estimate of risk and thereby the cost of equity. In the UK, regulatory bodies have almost exclusively relied upon the Capital Asset Pricing Model (CAPM) ${ }^{3}$, although lip-service is typically paid to alternatives such as the Dividend Growth Model.

In the early years in the UK following the privatisation of most regulated industries, the allowed returns of companies were on a "glide path" towards the estimated cost of capital: companies were allowed to keep part of the benefit from reducing costs more

\footnotetext{
${ }^{3}$ The overall cost of capital (WACC) is calculated as a weighted average cost of debt and equity finance: WACC $=g \times r_{d}+(1-g) \times r_{e}$ where $g$ is the gearing level (net debt/total value); $r_{d}$ is the return required on debt; and $r_{e}$ is the return required on equity. The CAPM states that a company's cost of equity is determined by the risk-free rate $\left(r_{f}\right)$, the equity risk premium (ERP) for the market as a whole, and the company-specific risk parameter, beta (measured by the ratio of the covariance of the returns on the company's shares with the those of the market in general, divided by the variance of the market returns): $r_{e}=r_{f}+$ beta $\times$ ERP. The cost of debt is usually estimated as the sum of the risk-free rate $\left(r_{\mathrm{f}}\right)$ and debt premium $\left(d_{p}\right)$ that investors require from investments in a company: $r_{\mathrm{d}}=r_{\mathrm{f}}+d_{p}$. As an alternative to the CAPM, the cost of equity is sometimes estimated using the Dividend Growth Model, which in its simplest form assumes that dividends grow at a constant perpetual rate. In this case the cost of equity is the sum of the current dividend yield and the assumed growth rate.
} 
quickly than assumed by the regulators at previous periodic reviews, and consequently earned returns considerably in excess of the cost of capital. However, now that the UK regulated utility businesses have been subject to multiple reviews, the glide path has ended and the estimated cost of capital is now much more closely related to actual (and expected) returns.

Estimating the overall cost of capital using the CAPM involves the following steps. First, the risk-free interest rate is estimated. This is, generally, the most straightforward part of the exercise, as forward-looking estimates are readily available from government bond markets. The main issues relate to (a) whether to use the latest "spot" estimates, or whether to apply some longer-term averaging (which might be important if there are concerns that current rates are unusual, and that companies may need to raise finance during the subsequent control period at very different rates), and (b) what maturity of debt to assume (this decision is usually bounded by the length of the control period - typically five years - and the economic life of the assets).

The second step involves estimating the company-specific debt premium. Again, this is normally not too difficult, especially for those companies with existing quoted debt. Even in the absence of such quoted debt, comparative information can be used from companies with similar operating and financial profiles. Issues of maturity and whether to use spot or longer-term averages apply equally to the debt premium. Combining the risk-free rate and debt premium estimates produces the overall cost of debt.

The third step then involves estimating the markets' valuation of equity risk - the equity risk premium (ERP). This is probably the least straightforward issue faced by regulators, not least because views on the appropriate value for the ERP differ significantly among academics and practitioners. Unlike in the case of interest rates, market evidence of forward-looking expectations are not available, and so there tends to be a strong reliance on historical evidence as a guide to future expected returns (see the discussion in Jenkinson, 1999). However, in recent years there has been an important reassessment of what the longer-term historical evidence actually shows for the ERP - in particular the important work of Dimson, Marsh and Staunton (2002) which has generally resulted in downward revisions to estimates of the ERP.

The fourth step is to estimate the (un-diversifiable) risk associated with the specific regulated activity. Within the context of the CAPM, this means estimating the beta coefficient, and again this necessarily relies upon historical data. We will focus on the difficulties encountered in estimating beta coefficients in the next section of the chapter, but this has certainly been one of the areas where regulators have become increasingly loath to rely upon the market evidence. Combining the beta and ERP estimates provides the cost of equity.

The fifth step involves weighting together the cost of debt and cost of equity to produce an overall weighted average cost of capital (WACC). Until recently, regulators tended to use actual debt/equity ratios in such calculations, but, as regulated companies have increasingly become highly geared, there has been a tendency to use "assumed" capital structures in setting the WACC. 
Finally, it is necessary to decide whether to set the cost of capital on a pre-tax or posttax basis. Clearly, investors care about the returns they receive from the company after it has paid any corporate taxes, and they have paid any income or capital gains taxes. Regulators have the choice, however, of allowing for such tax payments in the allowed cost of capital - thereby setting a pre-tax cost of capital - or including projected (corporate) tax payments in the allowed costs of the company, and setting a post-tax cost of capital on the RAV. In practice, adopting the former approach will usually involve using an assumed tax-wedge reflecting statutory tax rates, which is applied to the cost of equity (given that interest payments on debt are tax deductible at the corporate level). The use of statutory rates is fine when viewed over the long-term, or in equilibrium, but in the short-term the actual tax positions of companies can deviate widely from the statutory position. Setting a post-tax cost of capital will tend to reduce incentives to increase gearing for purely tax-driven reasons, especially if any benefits from increasing gearing above assumed levels are clawed back at subsequent reviews. General concerns to reduce the incentives for companies to adopt highly-geared capital structures provide one explanation for the increased tendency in recent years to set the cost of capital on a post-tax basis. ${ }^{4}$

In Table I we present a summary of a sample of the regulatory decisions regarding the cost of capital that have been made in recent years in the UK. For consistency, these have been put on a similar tax basis: given the trend towards using post-tax values, we have normalised on this measure. ${ }^{5}$ Looking over the recent history of regulatory decisions, there was a general downward trend in the estimates. In part this driven by falling real interest rates, especially as regulators started, from 1999 onwards, to put more weight on the current spot rates rather than the longer term averages (which was the justification for the range employed, for example, by the Monopolies and Mergers Commission in the 1996 BAA case). Also, as the stock market boomed until 2001, so estimates of the equity risk premium tended to be reduced. So, for example, in the case of OFWAT, the estimated cost of equity, and the overall WACC, fell noticeably between the periodic reviews of 1994 and 1999. Similarly, in the case of BAA, the overall WACC fell by a full percentage point from 6 per cent in 1996 to 5 per cent in 2002.

However, the other noticeable trend in the UK during the last few years has been the increasing use of debt in the capital structure of, in particular, water and electricity distribution companies. In principle, under the Modigliani and Miller (1958) assumptions, changes in the capital structure should have no impact on the overall WACC, in particular when measured on a post-tax basis, as in Table 1. As gearing increases, the equity beta should increase linearly (provided the underlying asset beta is constant) thereby offsetting any benefit from the greater use of cheaper debt. But there has clearly been a perception amongst regulated companies that the increasing

\footnotetext{
${ }^{4}$ For instance, OFGEM (the Office of Gas and Electricity Markets) consistently set the cost of capital on a pre-tax basis until the 2004 electricity distribution price control review, at which point it switched to a post-tax approach which "allows the incentives to increase gearing to be mitigated" (OFGEM, 2004b, p.111).

${ }^{5}$ To further confuse matters, the terminology “post-tax" has not been consistently applied in the past. The distinction between pre- and post-tax has tended to relate only to the cost of equity, with the cost of debt being assessed on a pre-tax basis. The figures in Table 1 measure both the cost of equity and the cost of debt on a post-tax basis.
} 
use of debt finance can lower the cost of capital, and as a result there has been a significant increase in gearing across the utility sector.

This has had various implications. First, regulators are increasingly concerned that their methodology for estimating the cost of capital should not encourage excessive use of debt. This in part explains the trend towards setting the cost of capital on a post-tax basis, where any tax-driven benefits from increasing gearing above assumed levels are clawed back at the next review. However, the main way that regulators have responded in recent years has been by increasing their estimates of the cost of equity finance - both in absolute terms and relative to the cost of debt. For instance, as Table 1 shows, in the most recent 2004 review of electricity distribution, the cost of equity has been estimated at 7.5 per cent real post-tax, whereas at the previous review in 1999 the range was estimated at 5.5 - 6.5 per cent. We discuss the problems regulators have encountered in estimating the appropriate cost of equity in the next section.

The second response to the increasing gearing has been for regulators to pay much more attention to financeability, and to consult those involved in the debt markets - in particular credit rating agencies - to a much greater extent. We discuss the merits of this response later in this chapter.

\section{Measuring risk}

One of the key requirements in establishing an appropriate cost of capital is clearly to estimate the risks associated with the activity. Standard finance theory informs us that investors should only require additional returns for bearing non-diversifiable risks which within the single-factor CAPM is captured by the beta of the company. However, one of the most difficult areas for regulators in recent years has been the estimation of such beta coefficients. Recall, also, that small changes in such estimates have significant implications: with an equity risk premium of, say, $4 \%$, then a movement of 0.25 in beta will change the cost of equity by $1 \%$.

As can be seen from Table 1, and from reading the determinations from which the figures are drawn, regulators have tended to use equity beta estimates that are surprisingly close to unity. To some extent, of course, the upward trend that can be seen in the equity betas should simply reflect the increased use of debt in the capital structure. However, it is nonetheless surprising that, for instance, water companies and electricity distribution companies - with revenues that vary hardly at all with the general state of the economy - should be assumed to have a risk profile similar to that of the average UK company.

There are various possible explanations for the high betas used by regulators. First, for some industries market evidence relevant to the regulated business has become increasingly scarce or difficult to interpret. There have always been concerns about the need to isolate regulated from unregulated activities of companies, but in some industries it has become more or less impossible to obtain a direct measure of risk. This is particularly the case in electricity distribution - where no pure electricity distribution companies with a separate stock exchange listing exist in the UK anymore - and in the case of the rail network - since the demise of Railtrack and its 
reincarnation as Network Rail (which is essentially funded by government guaranteed debt). In such cases, it is possible to look at comparator companies in similar industries, or at international evidence for the same industry, but this is usually a very imperfect substitute, since details of the regulatory contract - for instance in the extent of cost pass-through, or the sharing of quantity risks through revenue caps - will have a significant impact on risk.

The second, and related, explanation for the tendency to use beta estimates close to unity is that uncertainty about the "true" value - either due to the lack of reliable evidence, or instability in the estimates over time - should result in more weight being given to the unconditional expectation (in the absence of any specific information) that the companies are of average risk (and hence have a beta of unity). This point is specifically made by Ofgem in their most recent determination for electricity distribution (see Ofgem, 2004b, pp. 105-106). OFWAT, although acknowledging the market evidence that betas are much lower than unity, has also clearly been influenced by such views (see OFWAT, 2004, pp. 269-270). Consequently, for both the energy and water sectors, the current position is that equity beta is estimated at unity.

Whilst acknowledging the problems faced in measuring risk, it is nonetheless extremely surprising that the cost of equity is set on this basis. Consider the evidence for the water sector - which probably provides the least bad set of data for estimating betas. In Figure 1 the equity betas for the water sector are computed on a two-year and five-year rolling basis since privatisation. These estimates are derived using daily total returns for an index of UK listed water companies. The figure demonstrates clearly the problems faced by regulators. For much of the 1990s, the data was all pointing towards beta estimates in the range of 0.2 to 0.4. Although levels of net debt were increasing during this period there was no clear upward trend in the equity beta, as would, in principle, be expected if the underlying asset beta was unchanged.

However, the real problems with the estimates started during the stock market bubble years of 1999-2001, when estimated betas tumbled sharply and even turned negative (obviously with a lag of a few years in the case of the 5-year estimate). Indeed, although the two-year beta increased significantly in 2004 and at the end of 2004 was back at around 0.3, the estimated five-year rolling beta for the water sector at the time of writing remains negative. This is clearly implausible, and suggests that the period generating such odd results should carry less (or no) weight in cost of capital calculations.

But even given these obvious problems with the instability of estimated beta coefficients, it is extremely difficult to understand why regulators should assume that utilities are of average risk, notwithstanding their relatively geared capital structures. Given the evidence in Figure 1, it would be hard to justify a figure much above 0.4. Furthermore, regulators themselves frequently extol the low-risk nature of these utility businesses. So why have regulators arrived at, what appear to be, very generous conclusions about beta?

The first likely reason is a nagging doubt about the reliability of the CAPM framework in the context of regulated industries. The regulators commissioned a review (Smithers \& Co, 2003) of possible alternative models to estimate the cost of 
capital, but this concluded that no clear successor to the CAPM existed. A second possible reason is that for those sectors facing substantial capital investment programmes, historical measures of risk will not capture future uncertainties. For instance, OFWAT (2004, p.218) states: "Business risk in the water industry remains fundamentally low. ... However, there are some risks that cannot be eliminated. For example, capital programmes are a source of uncertainty, and it is important that we take account of these risks in setting the cost of capital. The size and nature of the funding requirement both past and future is a factor that has influenced our view on an appropriate cost of capital for the water sector.”

However, it is questionable how much influence such fears regarding capital investment should have in practice. After all, the cost of capital is being applied to the entire regulatory asset base, which, as noted in footnote 2, currently amounts to £35 billion in the case of water. Over the next five years, due to the large capital programme, it is anticipated that this asset base will grow to $£ 40$ billion. Do the risks associated with the existing asset base really justify a beta of unity? It is extremely difficult to see why, and, indeed, the low risk nature of the existing regulated asset base has been recognised by the relatively cheap debt financing that has been secured against it. Furthermore, it is not axiomatic that the uncertainties associated with a large capital programme will necessarily increase investors required returns. Many of these risks are diversifiable in nature, and so long as the regulatory contract allows for a reasonable degree of symmetry in terms of enjoying the benefits of unanticipated efficiencies, as well as bearing any cost over-runs, then the impact on the cost of capital may be negligible.

Therefore, the current situation regarding assessing risk in the regulated utility sector is quite opaque, and, on the face of it, seems to be rather generous. This is particularly true if the existing asset base can be thought of as having an established regulatory status, and therefore suffers little in the way of expropriation risk. Of course, this says nothing about the generosity or severity of the overall regulatory settlements: a generous cost of capital may to some extent be balanced by a regulator's very challenging assumptions on future operating or capital efficiencies when setting price caps. But these are separate matters, and the objective of regulators should always be to establish an appropriate cost of capital in order to encourage appropriate investment decisions.

In this section we have considered risk in isolation from general considerations of capital structure. However, arguably the main explanation for the apparent generosity of recent estimates of the cost of equity relates to a concern that the "flight of equity" should be halted. It is to these issues that we now turn. 


\section{Capital structure}

The increasing use of debt in the capital structure has been observed across all UK utilities in the last decade. At privatisation, most utilities had very little debt, and some had positive net cash balances. ${ }^{6}$ A combination of net investment, dividend policies/share repurchases, and acquisitions have steadily increased gearing. However, it is worth remarking that it is by no means the case that companies have all adopted highly geared structures: the financial structures of utility companies both within a particular sector, and between sectors, varies considerably. Nonetheless, as can be seen from Table 1, the assumed level of gearing in the case of most of the regulated industries is now over 50 per cent, and this is reasonably close to the average actual gearing observed in those industries.

One obvious question is: should regulators care about capital structure? In this section we consider this question from two, related, perspectives. We start by considering the effect of capital structure on the cost of capital per se, and then look at the broader questions relating to whether regulators should attempt to influence, or limit, the capital structure of regulated companies.

\section{Capital structure and the cost of capital}

In the context of the cost of capital, finance theory suggests that the overall cost of capital is determined by the underlying business risks, not by how the business is financed. The main objection to this theoretical position is that it ignores the effects of taxation. However, if the cost of capital is set on a post-tax basis, then this objection may not apply. But this assumes that the CAPM is applied consistently - with reliable estimates of equity betas and debt betas - which would thereby maintain the invariance of the cost of capital to gearing. As noted in the previous section, in practice regulators have increasingly assumed an equity beta of unity, and have separately assumed a gearing level. Despite the close connection in theory between these assumptions, the relationship is much less apparent in recent regulatory decisions. So, for instance, a beta of unity was applied by Ofgem to the electricity distribution companies in both 1999 and 2004, despite the fact that the assumed gearing increased from $50 \%$ to $57.5 \%$.

In this situation the gearing assumption clearly has a major influence on the out-turn WACC. If increased use of debt has no impact on the assumed equity beta, then higher gearing will always reduce the allowed cost of capital, since, implicitly, the underlying asset beta is lower.

On the other hand, if the cost of capital is being set on a post-tax basis, and tax payments are being allowed for separately as a cost, regulators would still have to determine their policy on the extent of pass-through of tax, since higher use of debt finance would tend to reduce tax bills, and hence required revenues.

It is worth noting, however, that the necessity to set an assumed (or target or maximium) level of gearing is not required when the cost of capital is set on a pre-tax basis. As explained earlier, the pre-tax approach tends to use statutory tax rates in

\footnotetext{
${ }^{6}$ A notable exception is the case of the National Air Traffic Services, which was sold to a consortium that financed the acquisition with 94 per cent debt. Furthermore, the ratio of debt to the regulatory asset value was 118 per cent.
} 
computing the tax wedge to be applied to the cost of capital. In the short term, the effective tax rates of companies can deviate very substantially from these statutory rates, but over the long term the average effective rate should be similar to the statutory rate. Using this approach, the impact of capital structure is only important in the sense noted above: namely, that the estimated betas should reflect the observed gearing over the period that the betas are measured, in order that the CAPM is consistently applied.

Regulators may have some residual interest in the actual level of gearing employed by companies even when the cost of capital is being set on a pre-tax basis, depending on the relative tax disadvantage of equity (which should be reflected in the allowed tax wedge). In practice, this depends upon the extent of dividend tax imputation, or, as in the UK in recent years, the extent of "shareholder relief" regarding the taxation of dividends. ${ }^{7}$ However, companies themselves have incentives to reduce their cost of capital, and so will tend to reduce their reliance on equity when it is taxdisadvantaged. If they do increase gearing, then regulators would simply incorporate the higher observed gearing into their cost of capital calculations at the next price control, and customers would, at that stage, benefit from any tax efficiencies.

Looking over the recent history of regulatory decisions on the cost of capital, the vast majority of regulators have employed this pre-tax approach to setting the cost of capital. This has always been the case with the Competition Commission (including when it was the Monopolies and Mergers Commission), Oftel (the telecommunications regulator, recent absorbed with the Office of Communications), the Civil Aviation Authority (CAA) (which regulates the main London airports), and Postcomm (which regulates the Royal Mail). In addition, until recently, Ofgem and the Office of Rail Regulation also set the cost of capital on a pre-tax basis. In their most recent determinations, both have switched to a post-tax approach. The only regulator to consistently set the cost of capital on a post-tax basis has been Ofwat, who have, not surprisingly, been particularly proactive in the capital structure debate.

\section{Should capital structure be regulated?}

However, in many respects, the real debate about capital structure goes beyond issues relating to the cost of capital. In particular, in the 2004 reviews of water and electricity distribution, given the loose application of the CAPM, the gearing assumption, arguably, had little direct impact on the outcome for the overall WACC. In recent years, the main issue has been the concern that companies might adopt financial structures that over-relied on debt, and were not able to absorb cost, or other, shocks, or leave capacity to fund new investment. The emergence of "thin equity" models for utility companies has raised a number of issues relating to capital structure which, whilst related to the cost of capital - in particular because the way the cost of capital is determined may provide incentives for adopting a particular capital structure

\footnotetext{
${ }^{7}$ The system whereby dividends avoided being taxed twice - once at the corporate level (via corporate tax) and once at the shareholder level (via income tax) - used to be ameliorated by the use of the imputation system involving the company issuing tax credits to individual shareholders. In the UK, such credits did not entirely remove the double taxation, but the effect was much reduced. In 1997, the tax system was significantly changed, and reclaimable tax credits were replaced by lower rates of income tax on dividend income. This is what we refer to as a shareholder relief system. For more information on these tax changes, see Bell and Jenkinson (2002).
} 
- raise more general issues about the regulatory contract and the operation of financial markets.

First, perhaps the most fundamental question is whether regulators should attempt to influence capital structure at all. After all, if the cost of capital is set at an appropriate level, then investors should be prepared to commit capital, and the choice of capital structure could be left to the management of the company. As noted above, incentives to optimize the capital structure (in respect of taxation, addressing principal-agent concerns, or other factors) would exist as long as the cost of capital was based at periodic reviews on the out-turn capital structure. This laissez faire attitude towards capital structure broadly conforms to the approach taken by the Competition Commission over the years. I would argue that there is much to commend this general stance, and that regulators should avoid being too prescriptive about appropriate capital structures.

However, this stance raises a second important issue: what happens if a regulated company becomes financially distressed? Should regulators limit gearing, or set incentives that effectively discourage the use of debt beyond a certain point? This is one of the main concerns regarding the adoption of almost entirely debt-financed structures for some utility companies.

Again, there are different approaches that can be taken. The laissez faire approach would acknowledge the potential disruption that could be caused by the insolvency of a regulated company and would make sure that robust arrangements for the transfer of the license of the regulated activity existed. Such arrangements were in place for some, but not all, regulated companies at privatisation, and subsequent legislation has generally incorporated such "special administration" clauses into the remaining licenses. However, beyond establishing such back-stop arrangements, the choice of capital structure would remain one for the management. If debt levels, for whatever reason, became unsustainable, then this should be reflected in the market values of the debt and equity, and/or result in the violation of debt covenants. It is likely that in such a situation the management would have to organise a financial restructuring, which would typically involve raising more equity financing (either directly, or by converting some debt into equity). This would doubtless be painful for the management, but there is no reason why the lights should go out or the water should stop running. In extremis, the company may be unable to raise additional financing, in which case the existing investors would have an interest in negotiating a sale of the company. There seems to be a healthy appetite for regulated companies from a variety of parties, including private equity firms, and there is no reason to believe that an orderly sale of the company could not be achieved.

The objections to this approach fall into three broad categories. First, it is possible that the insolvency of a utility company may have systemic effects that go beyond the individual entity. For instance, debt premia might rise for all companies in that sector, or in other regulated sectors. Regulation of capital structure might, therefore, be justified in order to avoid such negative externalities. This is clearly a possibility, but it is uncertain whether investors would reassess risk in this way, in particular if the problems facing the particular company were idiosyncratic. 
Second, there is a concern that companies operating with high gearing - or those bought mainly with debt at valuations at, or above, the RAV - might be more likely to cut back on areas of expenditure that are important in the longer term, but may be discretionary in the short term. This relates particularly to those expenditures - such as maintenance or renewals - where the effects on outputs are not necessarily direct in the short term. This might be a particular issue if interest rates rose, and the burden of interest payments reduced free cash flow significantly. Again, this is potentially a concern, but the direct way of addressing this is to develop better systems for regulators to monitor outputs and the condition of assets. Furthermore, annual reporting of operating and capital expenditures provides regulators with early warning of abnormal trends. From the viewpoint of the company, a highly geared financial structure is likely to be heavily hedged against interest rate volatility, and, in any case, the equity holders in the business ultimately care about the value of the company, and have no incentives to damage this. Again, it is not clear how valid this concern is, and regulation of capital structure is a rather indirect way of addressing it.

Third, there is a view that, at certain times, equity markets are "closed" and therefore in the event that companies faced financial distress, or needed to finance a major investment programme, they would be unable to raise new equity. Therefore, regulated companies should keep a reasonable buffer of equity financing to see them through such eventualities.

This argument, although often heard, does not, in my opinion, withstand close scrutiny. In what sense are equity markets “closed”? Most utility companies have high dividend yields, and if necessary dividends could be cut and the retained earnings reinvested in the regulated business. In this way debt/RAV ratios would be reduced. Furthermore, if an additional equity issue is required, then why would investors not subscribe? Increasingly, firms conducting secondary offerings use deep-discounted rights issues, which do not even require underwriting. If investors do not want to commit additional funds, they can sell their rights, and accept the resultant share dilution. Although new equity issues by utility companies are not commonplace in the UK, they have been observed - for instance United Utilities' recent rights offer, and the sale of Northumbrian Water by Suez in 2003. Furthermore, it seems odd to believe that equity investors would be unwilling to commit further funds whereas debt investors are willing.

An alternative interpretation of the view that equity financing is difficult, is that such capital raising, or dividend cutting, events give financial markets the opportunity to express their views about the management of the company, and that senior executives often face intense scrutiny. Therefore, it is not so much that financing cannot be raised, but that executives may not want to go to the equity markets. However, in the absence of any evidence of mis-management, it is difficult to understand why equity investors would exact management changes if additional funding was required for, say, a major investment programme that was going to result in an increased RAV, or why they would be unprepared to fund it (whether by debt or equity).

Therefore, although there are arguments for capital structure to be regulated, there are also good reasons for taking a laissez faire approach to capital structure decisions. If the cost of capital is set at a reasonable level, financing should be forthcoming, and there is no need to decide on a target, optimal, or maximum level of gearing. In the 
next section we consider an additional issue that has in recent years become a significant consideration in determining required rates of return: financeability.

\section{Financeability}

All the regulatory bodies have, as one of their duties, a requirement that the companies they regulate are able to finance their licensed functions. One interpretation of this duty, in line with the laissez faire approach explained in the previous section, is simply that it relates to the requirement that the regulators set an appropriate cost of capital for the regulated business. However, there has been an increasing weight given to a second requirement - to check on the prospective financeability of the company given its future capital and operating requirements.

For instance, Ofwat is particularly clear in its interpretation of its duties:

"We have a duty to secure that companies are able to finance the proper carrying out of their functions as licensed undertakers ('finance functions'). We look at this as having two strands. One is to secure that, if a company is efficiently managed and financed, it is able to earn a return at least equal to the cost of capital. The second is that its revenues, profits and cash flows must allow it to raise finance on reasonable terms in the capital markets. We refer to this second strand as financeability." (Ofwat, 2004, p. 217).

Financeability is particularly an issue when companies are required to undertake large capital programmes, and are therefore facing periods when depreciation allowances are insufficient to prevent negative cash flow. OFWAT go on to elaborate that in such circumstances there can be "a deterioration in credit quality which could restrict the access of companies, despite earning their cost of capital, to capital markets or could significantly increase the cost of finance.” (ibid).

The practical consequence of conducting such financeability tests, is that increasing emphasis is placed on prospective financial ratios - such as various versions of interest coverage, cash flow to debt ratios, and gearing ratios - and whether companies are expected to retain a strong credit rating throughout the price control period. Regulators increasingly turn to credit rating agencies for their views on such matters, and licenses have been amended in some cases to require companies to maintain an investment grade credit rating.

Such macro-level tests of the impact of the various parts of the regulatory determination on the finances of the company are clearly sensible, and have frequently been conducted by sectoral regulators and the Competition Commission. However, with the increased gearing of regulated companies, and the end of the glide path whereby past efficiency saving resulted in allowed returns well in excess of the cost of capital, financeability tests are increasingly starting to bind. This is particularly true of the water industry in England and Wales, where the recent final determinations 
for the 2005-10 price control period include financeability payments amounting to more than $£ 400 \mathrm{~m}$ in NPV terms.

The effect of such financeability payments is to set allowed returns at a level above the cost of capital. However, there are arguments against this two strand approach to judging an appropriate allowed return. First, as noted in the previous section, capital structure is largely a matter for management rather than the regulator. Financeability issues tend to follow directly from decisions over capital structure. Ideally, management should be taking a long-term view of the likely capital programmes they will be required to deliver, and set their capital structure appropriately. If they want to keep a stable dividend policy, and not tap the equity market for additional funds, then if they anticipate substantial future net investment they should retain the financial capacity by keeping current levels of gearing down at appropriate levels. If management misjudges such matters, and faces a credit downgrade, then they would have to repair their credit rating by raising additional equity financing. According to this narrow interpretation of the 'financing functions' duty of regulators, there is no need for regulators to involve rating agencies in their deliberations (notwithstanding the high levels of debt employed by some companies), nor for them to make additional payments over and above the cost of capital.

In practice, however, it can be difficult for management to anticipate the investment demands they are likely to face in the future. Such matters often involve all manner of government agencies and are subject to considerable political input. So in some cases it may be unreasonable to expect companies to be able to predict the future capital expenditure requirements and set an appropriate long-term strategy to finance these. In such cases, however, there are alternatives to allowing companies higher rates of return.

First, it is always open to the regulator to adjust the profile of prices within a control period to match the cash-flow profile. For instance, if a company faced particularly high first-year investment, allowed revenues could be increased in this year to keep financial ratios at appropriate levels. However, this approach tends to trade off stable price paths for consumers against stable financial ratios for companies. Furthermore, it is unclear why financial markets should be unduly influenced by financial ratios in any particular year, rather than those applying over the entire control period.

Second, if the cash-flow "problem" is such that it cannot be fixed by moving revenue around within a control period, then the regulator could alter the depreciation profile of the company and spread the effect over many years. This approach was considered, but ultimately rejected, by Ofgem for one company in their 2004 review of electricity distribution. However, advantages of such an approach are: (a) it is NPV neutral, since the extra depreciation reduces the RAV more rapidly and (b) in many cases it will lead to an equitable inter-temporal smoothing of prices over a number of control periods.

\footnotetext{
${ }^{8}$ A financeability payment has also been allowed by Ofgem in its recent price control review for the electricity distribution sector. For one company, an extra payment of $£ 1.6 \mathrm{~m} \mathrm{p}$.a. has been allowed to ensure that it is possible to "maintain a credit rating comfortably within investment grade" (Ofgem, 2004b, p.115).
} 
Therefore, although some regulators in the UK have added financeability allowances on top of the estimated cost of capital, I would argue that there are good arguments against this, and in favour of a narrower interpretation of their duties.

\section{Conclusions}

In this paper we have reviewed some of the important issues encountered by regulators when estimating the cost of capital. Although asset pricing models such as the CAPM are easy to implement in principle, we discussed some of the issues faced by regulators in practice. One of the main concerns has been how to estimate the risk for regulated companies, especially when the relevant beta coefficients are either unstable or unavailable. The approach currently adopted by some regulators - to assume that utilities, with their current financial structure, are of average risk relative to the market as a whole - seems questionable, and, perhaps, more driven by a desire to increase allowed equity returns to prevent a further substitution of equity by debt.

The chapter has also considered the related issues of the regulatory approaches to capital structure and financeability, and their relationship to the cost of capital. In general, I have argued that it was not necessary, or probably desirable, to attempt to regulate the capital structure and the various measures of financeability in addition to the cost of capital. If the latter is set an appropriate level, the former are, on the whole, matters for management not regulators. 


\section{References}

Bell, L. and Jenkinson, T.J., (2002), "New evidence on the impact of dividend taxation and on the identity of the marginal investor." Journal of Finance 57(3), 13211346.

Competition Commission (2002), BAA plc: A report on the economic regulation of the London airports companies (Heathrow Airport Ltd, Gatwick Airport Ltd and Stansted Airport Ltd), November.

Dimson, E., Marsh, P., and Staunton, M. (2002), Triumph of the Optimists, Princeton University Press.

Jenkinson, T.J. (1999), "Real Interest Rates and the Cost of Capital", Oxford Review of Economic Policy, 15(2), 114-127.

Modigliani, F. and M. Miller (1958), "The cost of capital, corporation finance and the theory of investment”, American Economic Review 48, 261-297.

Monopolies and Mergers Commission (1996), BAA Plc: A report on the economic regulation of the London airports companies (Heathrow Airport Ltd, Gatwick Airport Ltd and Stansted Airport Ltd), October.

Office of the Rail Regulator (2000), Periodic Review of Railtrack's Access Charges: Final Conclusions, October

Ofgem (2000), The Transmission Price Control Review of National Grid Company from 2001: Transmission Asset Owner - Final Proposals, September

Ofgem (2001), Review of Transco's price control from 2002, September.

Ofgem (2004), Electricity Distribution Price Control Review: Update paper, Office of Gas and Electricity Markets, September 2004.

Ofgem (2004), Electricity Distribution Price Control Review: Final Proposals, Office of Gas and Electricity Markets, December.

OFWAT (1994), Future Charges for Water and Sewerage Services: the Outcome of the Periodic Review, July.

OFWAT (1999), Future Water and Sewerage Charges, 2000-05: Final Determinations, Office of Water Services, November.

OFWAT (2004), "Future Water and Sewerage Charges: Final Determinations”, December 2004.

ORR (2003), Access Charges Review Final Conclusions, December.

Smithers \& Co (2003), "Study into Certain Aspects of the Cost of Capital for Regulated Utilities in the UK”, February. Available from the Ofwat website. 
Figure 1: Beta estimates for the UK Water sector

This figure shows 2-year and 5-year rolling betas since privatisation for the UK water sector (as represented by the Datastream UK Water index), relative to the FTSE-All Share index. The data frequency is daily.

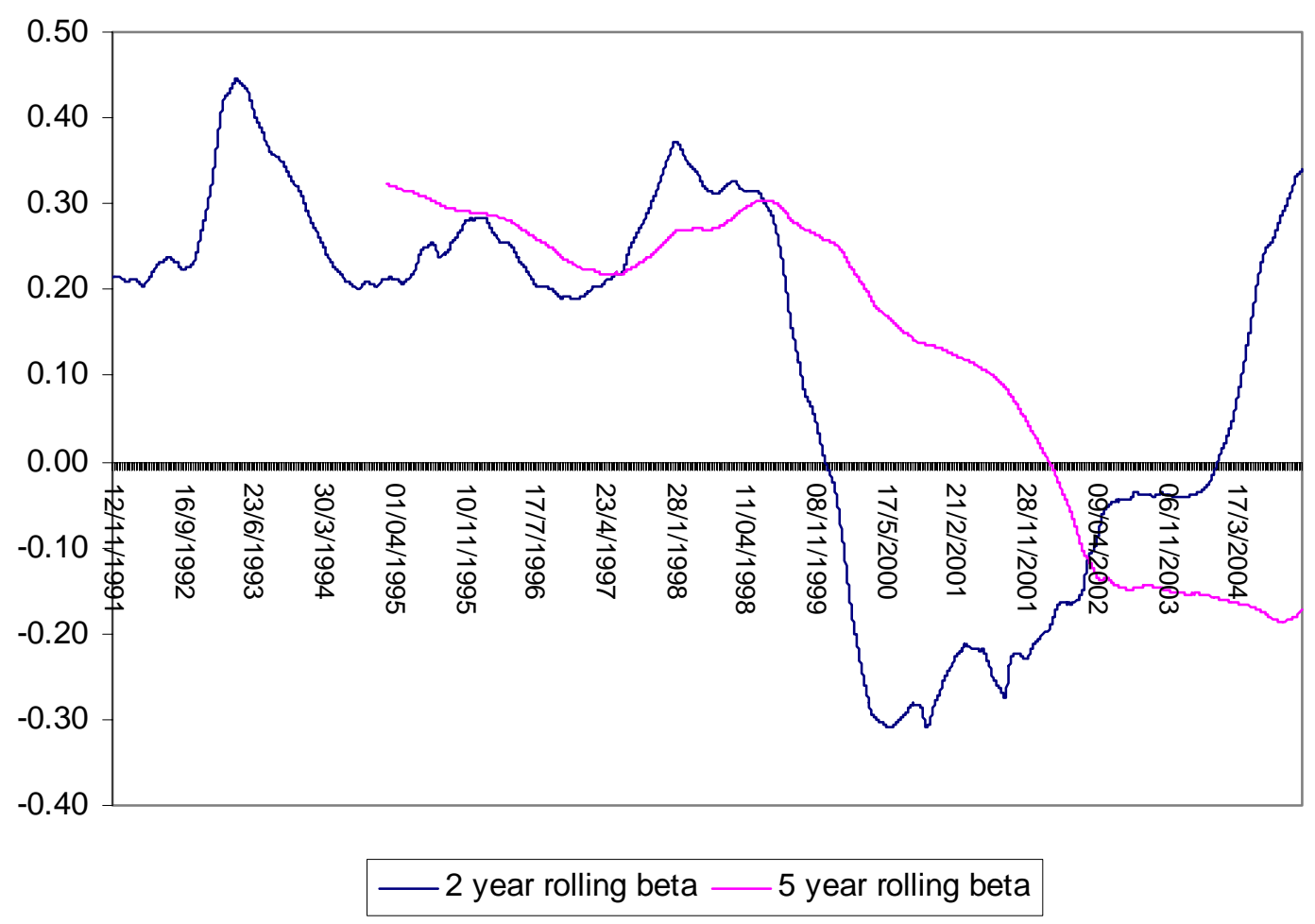

Source: Datastream 


\section{Table 1: Selected regulatory determinations for the cost of capital}

This table summarizes the cost of capital determinations for various UK regulated companies on a consistent real post-tax basis. It should be noted that in many cases the figures quoted by the regulators were on a different tax basis; in these cases the implied post-tax figures have been computed using an assumed corporate tax rate of $30 \%$ in order to compute the post-tax cost of debt. In the final column the resultant range for the WACC is presented, based solely upon adding up the component parts in the previous columns. This sometimes differs from the ranges quoted by regulators, which on occasions have been narrower than the range implied by the individual estimates. The final column also includes, in bold, any quoted "headline" cost of capital figure used by the regulator on a post-tax basis (for those regulators who use different tax bases, the headline figure has been calculated on a post-tax basis). When headline figures are not quoted, then the mid-point of the range is shown in bold. In the case of the most recent OFGEM review, little detail on the component parts of the cost of capital was published. In the interests of consistency over time and between regulators, the figures do not include small company premia that have been applied to the small water-only companies, nor any allowances for embedded debt (which were made by some regulators during 1999-2001).

\begin{tabular}{|c|c|c|c|c|c|c|c|c|c|}
\hline Regulator & $\begin{array}{l}\text { Industry and year of } \\
\text { the regulatory review }\end{array}$ & $\begin{array}{l}\text { Risk-free } \\
\text { rate } \\
(\%)\end{array}$ & $\begin{array}{l}\text { Debt } \\
\text { premium } \\
\text { (\%) }\end{array}$ & $\begin{array}{l}\text { Post-tax } \\
\text { Cost of } \\
\text { debt } \\
(\%)\end{array}$ & $\begin{array}{c}\text { Equity Risk } \\
\text { Premium } \\
\text { (\%) }\end{array}$ & $\begin{array}{l}\text { Equity } \\
\text { Beta }\end{array}$ & $\begin{array}{l}\text { Post-tax cost } \\
\text { of equity }\end{array}$ & $\begin{array}{l}\text { Gearing } \\
\text { debt }+ \text { equt } \\
\text { equity }\end{array}$ & $\begin{array}{l}\text { Post-tax } \\
\text { WACC }\end{array}$ \\
\hline OFWAT & Water (2004) & $2.5-3.0$ & $0.8-1.4$ & $2.3-3.1$ & $4-5$ & 1.0 & $6.5-8.0$ & $55 \%$ & $\begin{array}{c}4.2-5.3 \\
\mathbf{5 . 1 \%}\end{array}$ \\
\hline Ofgem & Electricity Distribution (2004) & & & 2.9 & & 1.0 & 7.5 & $57.5 \%$ & $4.8 \%$ \\
\hline $\begin{array}{l}\text { Competition } \\
\text { Commission }\end{array}$ & $\begin{array}{l}\text { London Airports - BAA } \\
\text { (2002) }\end{array}$ & $2.5-2.75$ & $0.9-1.2$ & $2.4-2.8$ & $2.5-4.5$ & $0.8-1.0$ & $4.5-7.3$ & $25 \%$ & $\begin{array}{c}4.0-6.1 \\
\mathbf{5 . 0 \%}\end{array}$ \\
\hline Ofgem & $\begin{array}{l}\text { Gas Transmission and } \\
\text { Distribution - TransCo (2001) }\end{array}$ & 2.75 & $1.5-1.9$ & $3.0-3.3$ & 3.5 & 1.0 & 6.25 & $62.5 \%$ & $\begin{array}{c}4.2-4.4 \\
\mathbf{4 . 4 \%}\end{array}$ \\
\hline ORR & Railtrack (2000) & 3 & $1.5-1.75$ & $3.15-3.3$ & 4 & $1.1-1.3$ & $7.4-8.2$ & $50 \%$ & $\begin{array}{l}5.3-5.8 \\
\mathbf{5 . 6 \%}\end{array}$ \\
\hline Ofgem & Electricity Distribution (1999) & $2.25-2.75$ & 1.4 & $2.6-2.9$ & $3.25-3.75$ & 1.0 & $5.5-6.5$ & $50 \%$ & $\begin{array}{c}4.0-4.7 \\
\mathbf{4 . 6 \%}\end{array}$ \\
\hline OFWAT & Water (1999) & $2.5-3.0$ & $1.5-2.0$ & $2.8-3.5$ & $3-4$ & $0.7-0.8$ & $4.6-6.2$ & $50 \%$ & $\begin{array}{c}3.7-4.9 \\
\mathbf{4 . 1} \%\end{array}$ \\
\hline $\begin{array}{l}\text { Monopolies } \\
\text { and Mergers } \\
\text { Commission }\end{array}$ & $\begin{array}{l}\text { London Airports - BAA } \\
\text { (1996) }\end{array}$ & $3.5-3.8$ & $0.3-0.8$ & $2.7-3.2$ & $4-5$ & $0.7-0.9$ & $6.3-8.3$ & $30 \%$ & $\begin{array}{c}5.2-6.8 \\
\mathbf{6 . 0} \%\end{array}$ \\
\hline OFWAT & Water (1994) & $3-4$ & 1.0 & $2.8-3.5$ & $3-4$ & $0.67-0.75$ & $5.0-7.0$ & $12 \%$ & $\begin{array}{c}4.7-6.6 \\
5.7 \%\end{array}$ \\
\hline
\end{tabular}

Sources: Ofgem (2004b, p. 109), OFWAT (2004, p.222), Competition Commission (2002, p. 171),Ofgem (2001, p.73), Office of the Rail Regulator (2000, p. 46-47),

OFWAT (1999, p. 130), Monopolies and Mergers Commission (1996, p. 81), OFWAT (1996, pp. 49-50). OFWAT is the Office of Water Services, Ofgem is the Office of

Gas and Electricity Markets, ORR is the Office of Rail Regulation. 